\title{
The Holy Register: Its Equivalence and Strategies
}

\author{
MatTheW Prattipati
}

\begin{abstract}
Lexical gaps pose an insurmountable problem before a translator who deals with two languages which are distanced by unbridgeable cultural differences. The present paper focuses on how certain techniques can be applied to ameliorate the word level problems posed by the non-correspondence of words and meanings between English and Telugu while translating religious texts. This paper puts forth a set of parameters for overcoming such problems.
\end{abstract}

Keywords: The Holy Bible, Translation, God, Holy Spirit, Temple, Telugu Translators and Equivalence

\section{Introduction}

This is an attempt to analyse the issues related to the great tradition of translation that one comes across while rendering the literary texts especially, of the religious genre into a target language. Translating is the process of transferring knowledge conveyed through source language texts. But translating religious text needs utmost care, attention, rigour and unfailing devotion to the work. It requires profound scholarship, unquestioned knowledge of two languages and the noble traditions of two different religious philosophies. The Telugu Bible translation has a vital span of about two hundred sixty 
five years of translation tradition and even today the tradition continues.

In this paper, I would like to focus on the word level assessment of the Holy register in general and the concepts in particular. It is built on the translational dynamics of three concepts namely:
1. The God (Old \& New Testaments $\left(\mathrm{NT}_{1}\right)$
2. The Holy Spirit (New Testament) $\left(\mathrm{NT}_{6}\right)$ and
3. The Temple (New Testament) $\left(\mathrm{NT}_{7}\right)$

The translators involved in this are native, non-native individuals and also some Christian institutions. For instance, Augustus Des Granges, William Carey, Edward Pritchett, John Gorden and John Hay are non-native translators. The native translators are Gudipati Venkatachalam, Father D. Thomas, Kondaviti Venkatakavi, Father Pudato Jojayya, G.R. Lorne and the Christian institutions are Madras Auxiliary Bible Society, Addison \& co., Madras, Bible Society of India and World Bible Translation Centre, Bangalore etc.

The scheme of this paper is a four dimensional evaluation of every linguistic item that comprises word in terms of its form, function, meaning and also there is a strategy for checking out its equivalence. For the present study, the English (Revised Standard Version) Bible is used as the source text.

\section{Objectives}

The objective of this paper is to test the equivalent terms for some of the holy registers translated from the English Bible into Telugu. The source language under study is claimed to be Hebrew, Greek and Latin. In the case of only one translation, it 
is Latin. The Protestant, Catholic and other translations (whichever may come under the particular period) are also taken for examination. The study has incorporated altogether twenty-nine specimens: nineteen from the New Testament (NT) and ten from the Old Testament (OT). The translation works into the target language (Telugu) span over a period of nearly two hundred years (1812 to 1993).

The primary focus of this study is to justify the equivalence of some Holy Registers by calculating their frequency of use. The judgment is based on sociolinguistic, semantic, linguistic and equivalence theory of translation. It is an impressionistic study, whose result reflects subjectivity as well as some degree of objectivity.

Altogether 33 parameters are created which are spread over 4 broad areas: formal aspects, functional aspects, semantic aspects and equivalence theory of translations. Each aspect includes stable broad parameters, for instance, formal aspect takes care of morphological structure of the word, whether it is simple, complex, compound or derivative. As for example, the term $g u D i$ refers to the simple word 'temple', mandiramu for complex, deewaalayamu for compound and aalayamu for derivative. The derived term refers to the terms of Sanskrit origin. All the parameters are given in the chart. The second one is the functional aspect, in this there are five broad areas namely (i) language specific (ii) frequency of usage (TL Oriented) (iii) Religious load (conceptual) (iv) classes of identification and finally (v) the class of users (TL Oriented); each of these five categories were again divided into three more subcategories. In the language specific category, we have three subcategories, which indicate whether the translator had retained the SL or created a TL word or borrowed word from any other language. For instance genesiisu is the best 
example of retaining the SL word Genesis where the translator has incorporated the SL word genesis and nativised it.

In the case of TL word, for the concept 'Temple' the translator has used the native term $g u D i$ which gives the same meaning. And there are some words like spiritu saanktu $\left(\mathrm{NT}_{19}\right)$ for the concept 'The Holy Spirit' and for the concept of God/yihuhu/ $/ \mathrm{NT}_{2} /$ yehoowaa/ $/ \mathrm{NT}_{11}=\mathrm{YHWH}$ were given in $\mathrm{TL}$ text where these translated words are borrowed from Latin and Hebrew, respectively.

\section{Frequency of Use (TL Oriented)}

As Genesis and St. Luke are my points of concentration, I have taken a given sentence out of nineteen translated versions of the New Testaments (NT) and the other ten versions of the Old Testament (OT) and found out the frequency of use of a given word in a particular sentence. For example see 4.1. where the term deewuDu refers to God is used by fourteen translators, which takes the highest number of occurrences in the OT and NT. Prabhuwu refers to Lord is the other term that is used by nine translators which takes the medial position. The words like karta, sarveSwaruDu, yahoovaa God are used by some translators.

Religious Load (Conceptual): In the case of religious load, according to the flow chart, one should see whether the translated concept is a concept or adopted according to the nature of the TL or it is borrowed from a foreign tongue. For example, baptiismamu refers to Baptism is very much SL oriented. And in the case of diivena means blessing is very much in accordance with the native rendering. The term spiritu saanktu (see 4.2) means the Holy Spirit is a borrowed word from the Latin. 
The Class of Identification: In this category, we have three labels personal, social and general, where the identity of the translated word is directed towards the personal or its social relevance or towards its generic nature respectively. Apart from that, they also reveal the translator's discerning capacity in terms of his attachment to the social stratification and economic factors. The example for the label person is iiswaruDu means God which indicates + masculine + human.

The word 'slave woman' is a social entity which carries certain amount of social significance so the category social incorporates in itself the different layers and segments of the socio-economic stratification. The translated words for 'slave woman' are daasi $\left(\mathrm{OT}_{2}-7,9,10\right)$, baanisa (OT-8). The category general indicates the particular preference of the translator for a general term for a conceptual word. For example, for the concept 'custom', one of the translators (NT11) has used a general word idiwarakumalleene means 'like earlier'. None of the translators has used accurate term and appreciated the term aachaaram for the concept 'custom'.

Class of Users (TL Oriented): This category consists of three sub-categories: educated, uneducated and common to all. This particular category and its sub-categories indicate the kinds of users who are prone to use various kinds of translated conceptual words. For example, the word 'pratibimbamu' means image, is found in the usage of educated people and aakaaramu meaning image and pooli $(\mathrm{ka})$ meaning image are found in the usage of uneducated and common users.

Semantic Aspects: In this area, one has seven subcategories of various ranges of their semantic use and preference. Firstly, they indicate whether a concept is retained 
as it is or slightly modified or any loss of meaning has taken place, or any descriptive analysis is given; in case the concept could not be retained as it is. Secondly, they indicate whether the concept signifies its primary meaning or secondary applied meaning or it is bound by any specific context. The appended chart No. III gives the examples for the above mentioned categories.

Equivalence: This aspect is based on the theories of Catford, Savory, Nida, Newmark and others. There is a sharp contrast among the aspects which they have discussed namely, formal, functional, semantic and equivalence. I deal with the equivalence here. The subcategories reflect the internal subtle difference which is very much essential to be considered for religious text translation. These sub-categories of equivalence are bound to the translation theories. These sub-categories of equivalence also indicate whether the word is formal or dynamic, free or bound, partial or complete in its sense. Finally, the last category "irrelevant" refers to the inadequacy of knowledge of the translator that made misrepresentation of the concept and such translated words are considered as "irrelevant" words. For example, for the concept of God, deewuDu is the formal equivalent term and iiswaruDu is dynamic equivalent and karta is a general term, used as an equivalent. And Yahoowa is also borrowed from Hebrew used in the translations. This also indicates that the equivalence used is complete or partial or retained its intended meaning in totality or out of ignorance; the translators used inadequate terms in the TL.

For the concept of temple, guDi gives the complete meaning and mandiram gives the partial meaning in Telugu. In case of God, the meaning iiswaruDu is partial, where the source language religious load is not found, but in the case of 
deewuDu, the meaning is complete where it handles both the SL and TL religious loads.

\section{Use of the Chart:}

1. The parameters of the chart are valuable in a number of ways especially for the translators and critics or evaluators.

2. The elaborate parameters will be very useful for translating Biblical literature as well as any other literary works. On the basis of the chart or by using the parameters stated, one can test, evaluate and judge the holy registers as well as other lexical items that come into existence and struggle for their acceptance within any language. One can also assert the appropriate equivalent terms, so that they are easily acceptable, widely used and consequently language is enriched. so that indirectly this chart aims at enrichment of any language by incorporating and giving stability to the terms once created and used in the body of its literature.

\section{EXPLANATION OF THE CONCEPTS}

\section{THE GOD; (Genesis 1: 6, St. Luke 1:6)}

$\begin{array}{ll}\text { iiswaruDu } & (\text { OT:1) } \\ \text { deewuDu } & \text { (OT: 2-10), (NT: 12, 13, 15, 17, 18) } \\ \text { karta } & (N T: 1-3) \\ \text { yihuwa } & (N T: 2) \\ \text { Prabhuwu } & (N T: 4-8,10,14,16) \\ \text { sarveeswaruDu } & \text { (NT: 9) }\end{array}$


yahoowa

1. IiswaruDu is a concept of God, which does evoke the sense of God perceived in Christianity. Karta is also Hindu concept of creator; hence, the scope of God cannot be limited to a creator. The terms Prabhuwu and eelinawaaru are frequently attached with the King or Lord or Master, which attaches reverential social status more than divinity. The Catholic Jargon eelinawaaru also refers to Bishop. Although the term 'sarveeswaruDu' is an equivalent to Almighty, it does not replace the sense of God in the target language.

2. For the concept of God the NT translators $(2,11)$ translate as Yihuwu and Yahowa. Keeping the concept of God in mind, the Telugu Bible translators go back to the original source language(s) like Hebrew (and Greek), and borrow directly the concept 'YahWeh' (YHWH) with slight phonetic variation. If we consider God as a simple word, deewuDu is more appropriate.

\section{THE HOLY SPIRIT ${ }^{1}$ (St. Luke 2:26) (NT)}

$\begin{array}{ll}\text { parisuddha aatma } & (\mathrm{NT}: 1) \\ \text { dharmaatmuDu } & (\mathrm{NT}: 2) \\ \text { parisuddhaatma } & (\mathrm{NT}: 3-10,14,16) \\ \text { iiswarateejassu } & (\mathrm{NT}: 11) \\ \text { pavitraatma } & (\mathrm{NT}: 12,13,15,17,18) \\ \text { spiritu saanktu } & (\mathrm{NT}: 19)\end{array}$


1. One of the NT translators (2) uses the word dharmaatmuDu for the concept of the Holy Spirit. It has more social appearance and relevance than the religious load, which the term Holy Spirit has. Besides this, dharmaatmuDu is + human, and whereas the Holy Spirit is - human $^{1}$, so the word dharmaatmuDu is quite opposite to the concept of the Holy Spirit.

2. The concept of iiswarateejassu (11) is used for the Holy Spirit. It carries the target language culture and religious load more than the source language religious load. Iiswarateejassu belongs to the Hindu religious world, whereas the Holy Spirit is purely a Christian concept.

3. And another translator (19) of NT, borrows from Latin. Sanctus Spiritus as Spiritu saanktu, which carries the same meaning of the Holy Spirit.

4. Among the translated terms for the word 'Holy Spirit- parisuddha aatma (difference of sandhi variation) and pavitraatma are somewhat closer to the concept of source language. When we come to the term, 'parisuddha aatma', the addition of emphatic prefix "pari" to the term "sudda aatma" sounds more pedantic and more obscure, which cannot be equated with the term pavitraatma that is more acceptable and easier and equivalent to the term Holy Spirit.

THE TEMPLE: St. Luke2: 46 (NT)

\section{Manddiramu $\quad$ (NT:1)}




$\begin{array}{ll}\text { Mandiramu } & (N T: 16) \\ \text { guDi } & (N T: 2,4-8) \\ \text { deewalam } & (N T: 13,15) \\ \text { deewaalayamu } & (N T: 9,10,12,14,16,17,19) \\ \text { aalayam } & (N T: 11)\end{array}$

Mandiram is a sacred place for the Hindus which requires the association of some deity (God/Goddess). For example, Krishnamandir, Jain mandir etc. Between mandiramu and mandiram, the first one is of classical variety of writing and the latter one is of modern variety. Manddiramu belongs to the old form of writing system and also has stylistic variations like granathika of that time. At present we are using wyaavahaarika (spoken variety), as Mandiram belongs to wyaavahaarika style. There is no change in basic meaning.

Though aalayam denotes the concept of temple, it is not widely used and it always carries the Hindu religious load by mostly taking the prefixes like raama, siva and mantra where they all are made compounds like raamaalayam, sivaalayam and mantraalayam respectively. So it is far from being the nearest equivalent to the term temple.

The term 'deewaalayam' evokes the picture of a pious Hindu place where any God may be instituted, and above all this term is descriptive. The term deewaalayamu belongs to graanthika style and deewaalayam belongs to wyaawahaarika.

Some of the translators use native term $g u D i$ for the term temple as an equivalent which is more acceptable when compared to others. All other words derived from Sanskrit, except $g u D i$, are the suitable equivalents for the term temple. 


\section{Findings}

The study reveals that the act of translation is motivated by a desire to transfer the message as perfectly as possible. But, the translators are conditioned by time, space, education, social norms, cultural background, linguistic competence and the knowledge of the target language culture. Due to this reason, there is no uniformity in the selection and the use of lexical items discussed under the study. All the varieties discussed above indicate the fact that the target language readers are confused in the different versions of translation. Consequently, the language stability and its standardization become slow and difficult.

From this experience, one has to learn a big lesson that for the sake of uniformity, the easy access to the translation, some authentic body or authority should regulate, guide and enhance such translation works, which urgently demands the preparation of bilingual dictionary through which a whole range of more appropriate terms will be presented and popularized to maintain uniformity.

\section{Note}

1. Yet, it is also held that the Holy Spirit is + human, basing on the Trinitarian concept of the Holy Bible, where the attributes of the Jesus Christ, who is + human and a part of the Trinity are very much applicable to the Holy Spirit and the Father God as well.

\section{References}

Catford. J. C. 1965. A Linguistic Theory of Translation. London: Oxford University Press. 
Lutfipjur - Saedi, K. 1988. Literature in Translation, ed. by Pramod Taigeri and S.B. Verma. Bombay: Popular Prakashan.

Newmark, P. 1981. Approaches to Translation. Oxford: Pergamon Press.

Newmark, P. 1988. A Textbook of Translation. London: Prentice Hall.

Nida, E. A. 1961. Bible Translating. London: United Bible Societies.

Nida, E. A. 1964. Toward a Science of Translating. Leiden: E.J. Brill.

Nida, E. A. and Taber C. R. 1974. The Theory and Practice of Translation. Leiden: E.J. Brill.

Nida, E. A. 1984. Signs, Sense, Translation. Cape Town: The Bible Society of South Africa.

Savory, T. 1968. The Art of Translation. London: Jonathan Cape.

Subramanian, K. 1988. Translation as Synthesis, ed by K. Karunakaran, M. Jayakumar. New Delhi: Bahri Publications.

* This paper was presented in $24^{\text {th }}$ All India Dravidian Linguistic Conference and revised. I thank Prof. William Bright, Prof. James R. Daniel for their valuable comments on the earlier draft. 
The Holy Register...

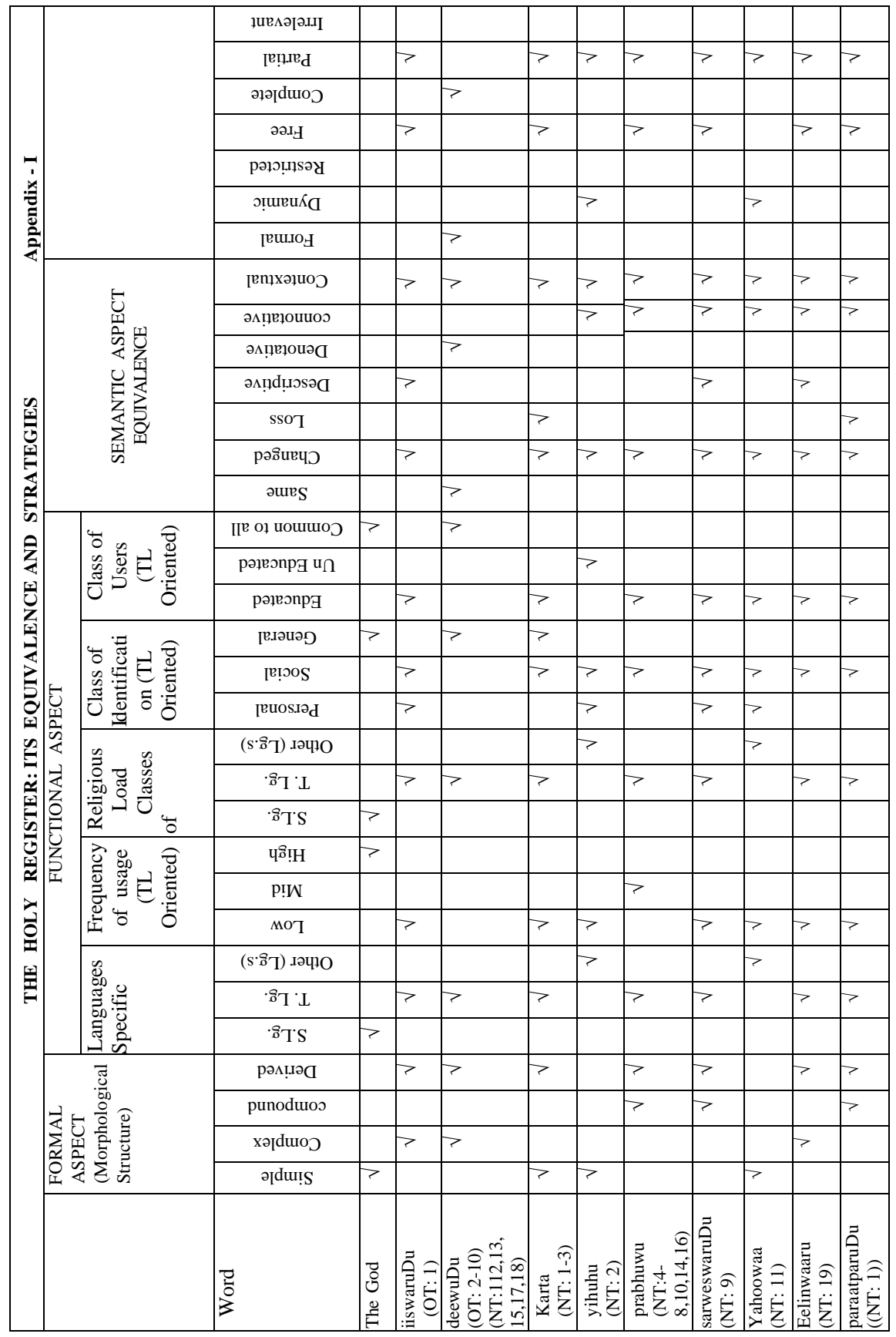




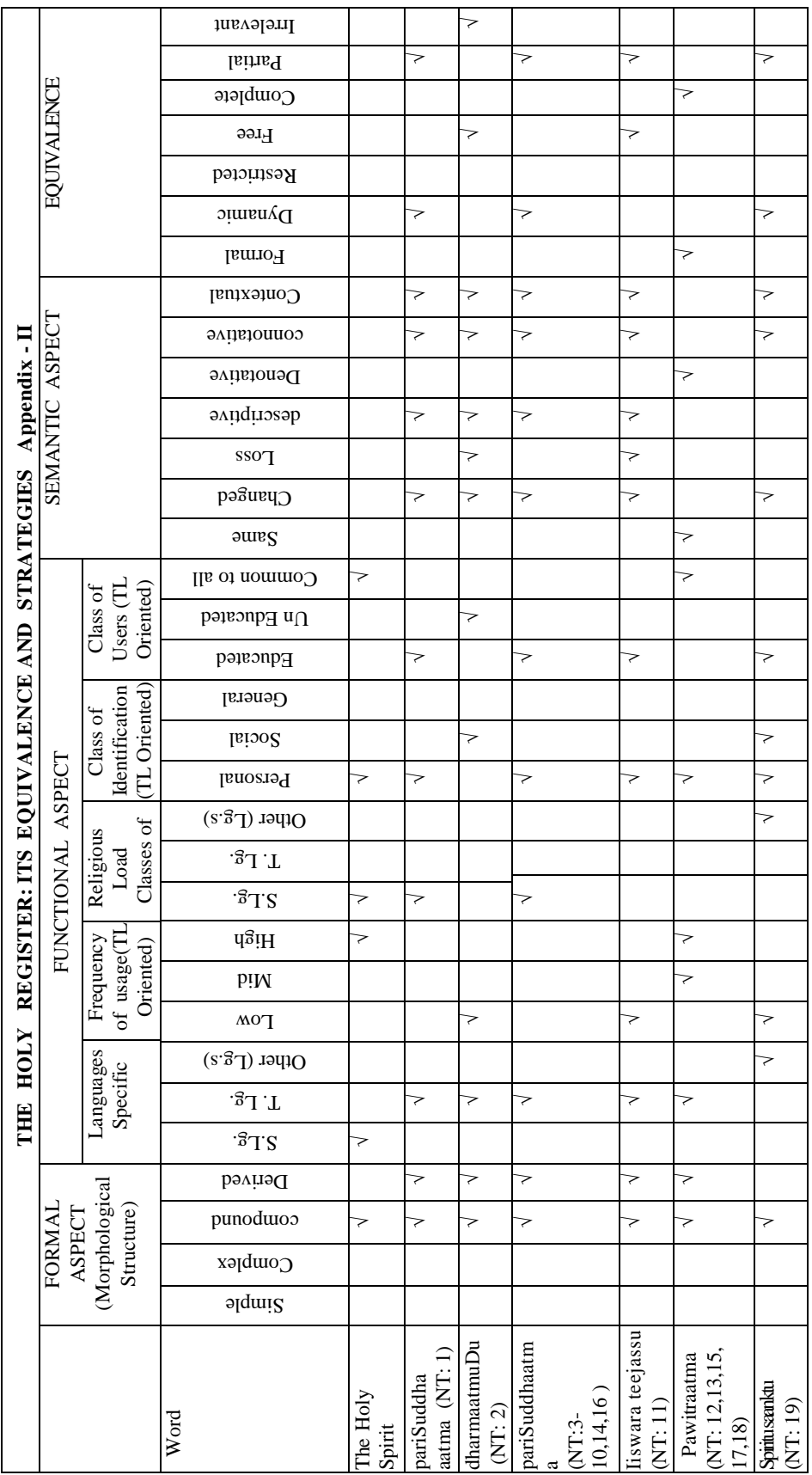


The Holy Register...

\begin{tabular}{|c|c|c|c|c|c|c|c|c|c|c|}
\hline \multirow{7}{*}{\multicolumn{2}{|c|}{ (2) }} & & ұив & & & & & & & \\
\hline & & & [ए!].IE & & $>$ & $>$ & & $>$ & $>$ & $>$ \\
\hline & & & 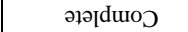 & & & & $>$ & & & \\
\hline & & & әәш⿴囗口 & & $>$ & $>$ & & & & \\
\hline & & & 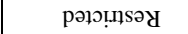 & & & & & & & \\
\hline & & & ग̣шеu $\widehat{~}$ & & & & & $>$ & $>$ & $>$ \\
\hline & & & [вш..о, & & & & $>$ & & & \\
\hline \multirow{7}{*}{\multicolumn{2}{|c|}{ 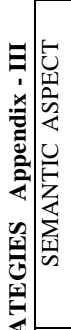 }} & & ¡впџхәџшоว & & $>$ & $>$ & & $>$ & $>$ & $>$ \\
\hline & & & 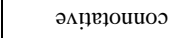 & & $>$ & $>$ & & $>$ & $>$ & \\
\hline & & & әм!̣єาоนว & & & & $>$ & & & \\
\hline & & & әц!̣d!̣.юsәр & & & & & $>$ & $>$ & \\
\hline & & & sso7 & & & & & & & $>$ \\
\hline & & & рәธินечว & & $>$ & $>$ & & & & \\
\hline & & & aurs & & & & $>$ & & & \\
\hline 善 & \multirow{3}{*}{\multicolumn{2}{|c|}{ 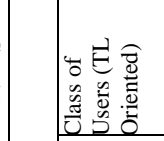 }} & I[ए & $>$ & & & $>$ & & & \\
\hline$\theta$ & & & рәңеэnрв u & & & & & & & \\
\hline$\pi_{4}^{2}$ & & & рәэеопр日 & & & & & & & \\
\hline $\mathbf{z}$ & \multirow{12}{*}{ 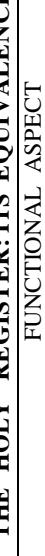 } & \multirow{3}{*}{ 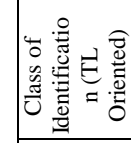 } & [Е.љиәр & & & & & & & $>$ \\
\hline 光 & & & [ए!̣OS & $>$ & $>$ & $>$ & $>$ & $>$ & $>$ & $>$ \\
\hline 3 & & & [euos.r. & & & & & & & \\
\hline$\underset{\text { O }}{\mathbf{O}}$ & & \multirow{3}{*}{ 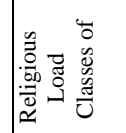 } & (s`o̊ & & & & & & & \\
\hline$\infty$ & & & ๑ 87 & & & & & & & \\
\hline$\ddot{\ddot{\sim}}$ & & & '8ิT'S & $>$ & & & & & & \\
\hline 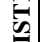 & & \multirow{3}{*}{ 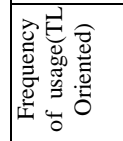 } & บชิเก!H & $>$ & & & $>$ & & & \\
\hline 牙 & & & $\mathrm{p!n}$ & & $>$ & $>$ & & $>$ & $>$ & \\
\hline 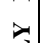 & & & MоT & & & & & & & $>$ \\
\hline$\overline{0}$ & & \multirow{3}{*}{ 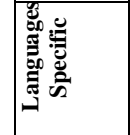 } & 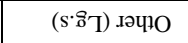 & & & & & & & \\
\hline 되= & & & 今ั $\mathrm{T} \cdot \mathrm{L}$ & & $>$ & $>$ & $>$ & $>$ & $>$ & $>$ \\
\hline$E$ & & & 'ิ T's & $>$ & & & & & & \\
\hline \multirow{5}{*}{\multicolumn{3}{|c|}{ 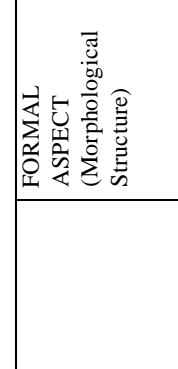 }} & рәм!юә & & $>$ & $>$ & & $>$ & $\rightarrow$ & $>$ \\
\hline & & & punoduos & & & & & $>$ & $>$ & \\
\hline & & & 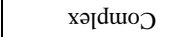 & & $\rightarrow$ & $>$ & & & & \\
\hline & & & ग्du!s & $>$ & & & $>$ & & & $P$ \\
\hline & & & $\begin{array}{l}7 \\
0 \\
3\end{array}$ & 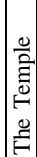 & 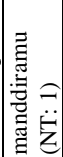 & 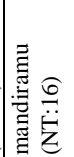 & 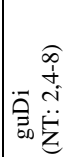 & 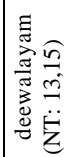 & 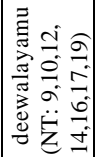 & 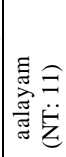 \\
\hline
\end{tabular}

